\title{
Annual report of the chairman of the Anglo-Belarusian Society for 2016
}

\author{
BY \\ BRIAN BENNETT
}

In 2016 we held an AGM, marked Mother Language Day, Kupalle, Kaliady and Batlejka, co-sponsored or otherwise supported a conference on Belarusian Studies in the twenty-fi rst century, a symposium marking Prof. Arnold McMillin's $75^{\text {th }}$ birthday, and organised a visit to the Slovak Embassy in London to hear the Ambassador talk about Belarus in a European context. We were pleased to witness the laying of the cornerstone and later the consecration of the new wooden Uniate church next to Marian House, the Society's traditional meeting place.

At the Annual General Meeting on 30 January 2016 we elected the Society's officials, reviewed the year just past and looked forward to events in 2016, the first of which was Mother Language Day, organised jointly with the Belarusian Sunday School and the Francis Skaryna Belarusian Library and Museum, and held in Marian House on 20 February.

On 23-24 March 2016 the UCL School of Slavonic and East European Studies (SEES) and the Ostrogorski Centre organised a conference at UCL entitled "Belarusian Studies in the 21st Century" in partnership with the Francis Skaryna Belarusian Library and Museum, the Journal of Belarusian Studies and the Society The conference ended with the second Annual London Lecture on Belarusian Studies entitled "Explaining Lukashenko's Survival" delivered by Professor Andrew Wilson, and a reception sponsored by the Society.

A Symposium was held 24-25 June to mark the $75^{\text {th }}$ birthday of Professor Arnold McMillin, Vice President of the Society. Held at SEES, it was supported by the Modern Humanities Research Association, the Association of Belarusians in Great Britain, the Belarusian Catholic Mission, the Francis Skaryna Belarusian Library and Museum and the Society, and attended from Belarus by Andrej Chadanovic, Hanna Kislicyna, Viktar Marcinovic and Uladzimir Niakliajeu. It was followed immediately by Kupalle (Midsummer) celebrations on 25 June at Penn Road.

On 19 November HE Lubomir Rehak, Slovak Ambassador to the UK, gave a talk entitled "Belarus in a European Context" to the Society at his Embassy in 
Kensington Palace Gardens. Mr Rehak speaks Belarusian (though he gave his talk in English) and served in Minsk as Charge d'Affaires 2006-8.

Other events marked as 2016 drew to a close were the traditional Kaliady and Batlejka in December. 